\title{
Variation in fatty acid composition of the bigeye snapper Lutjanus lutjanus collected in coral reef habitats of the Malaysian South China Sea
}

\author{
Takaomi Arai ${ }^{*}$, Razikin Amalina ${ }^{1}$ and Zainudin Bachok ${ }^{2}$
}

\begin{abstract}
Background: In order to understand trophic ecology, habitat use and migration of coral reef fish, fatty acid composition and levels were examined in the bigeye snapper Lutjanus lutjanus collected in the Malaysian South China Sea.

Results: Proportions of saturated fatty acids (SAFA) ranged from $55.0 \%$ to $66.5 \%$, with the highest proportions in fatty acids, the second highest was monounsaturated fatty acids (MUFA) ranged from $30.7 \%$ to $40.2 \%$ while the proportion of polyunsaturated fatty acids (PUFA) was the lowest ranged from 2.8\% to 4.8\%. Palmitic acid (16:0) was the most common in SAFA, oleic acid (C18:1 W9c) was the dominant in MUFA and linolenic acid (C18:3n3) showed the highest value in PUFA. Fatty acid concentrations, especially in SAFA and MUFA, increased with fish growth, suggesting diet and habitat shifts during the fish life history. Most of the fish had more than 1 of EPA: DHA ratio, which suggested that diets of L. lutjanus tended to be higher trophic organisms such as zooplankton and crustacean in coral ecosystem.
\end{abstract}

Conclusions: The diet shift revealed by the composition and levels of the fatty acid profile revealed potential pattern in the habitat use and migration scale in coral reef environment of L. lutjanus.

Keywords: Coral fish, Diet, Habitat, Lutjanidae, Migration, South China Sea

\section{Background}

Southeast Asia is recognised as the global centre for coral reefs, both in terms of extent and species diversity. An estimated $34 \%$ of the Earth's coral reefs are located in the seas of Southeast Asia, which occupy only $2.5 \%$ of the Earth's total sea surface [1]. Ecologically, the coral reefs of the South China Sea are sources of larvae and juveniles for many commercially important reef fish. 710 species of marine fishes from the Malaysian water and their adjacent seas are reported [2]. Furthermore, Ambak et al. [3] and Chong et al. [4] listed 2243 and 1951 fish species, respectively, in Malaysian water. Thus, Malaysia has the one of the highest and richest diversity of fish in the world [5]. Although several information regarding taxonomy and distribution in coral fish species is available in Malaysian water, few studies have been

\footnotetext{
* Correspondence: arai@umt.edu.my

'Institute of Oceanography and Environment, Universiti Malaysia

Terengganu, 21030, Kuala Terengganu, Terengganu, Malaysia

Full list of author information is available at the end of the article
}

done for their life history, ecology and reproduction compared to other coral reef areas.

Information on the diet and trophic position of an animal is fundamental issue to understand its life history. Recently, signature of fatty acid analysis has been increasingly used to study the diet of a number of marine species [6-11]. The use of fatty acids as trophic biomarkers is based on that many fatty acids in the marine environment are characteristic of specific groups of marine organisms [7,9-11]. Fatty acids can generally not be synthesised in higher trophic levels and are incorporated into the consumers' tissues with minimal modification, thus retaining signatures of their dietary origin [12]. Once fatty acid patterns are established for prey, they can be used to trace food webs and diets of higher predators. Thus, fatty acid analysis could support to resolve trophic interactions in marine ecosystems.

Bigeye snapper Lutjanus lutjanus is a commercially important coral reef fish species, geographically distributed in the Indo-West Pacific from the Solomon Islands 
to East Africa and from Australia to southern Japan [13]. The species is found in large schools of more than 100 individuals with other Lutjanus species [13,14]. Lutjanus lutjanus can reach a maximum of $30 \mathrm{~cm}$ in total length but generally grows up to $19 \mathrm{~cm}[13,15]$. As a carnivorous species, preys of Lutjanus species are believed to be small fishes and crustaceans [13]. However, diet and feeding ecology of the fish is scarcely understood.

In the present study, fatty acid analyses were used to investigate the trophic ecology of the bigeye snapper Lutjanus lutjanus collected in Malaysian South China Sea. To understand the trophic position in accordance with the growth, fatty acid signatures were compared using various size class samples. These fatty acid data will also be useful in food web studies to understand coral reef ecosystems.

\section{Results}

\section{Biological characteristics}

Biological characteristics such as TL and BW of the bigeye snapper Lutjanus lutjanus ranged from $13.2 \mathrm{~cm}$ to $19.5 \mathrm{~cm}$ and from $30.6 \mathrm{~g}$ to $109 \mathrm{~g}$, respectively (Table 1 ). Significant differences were found among three size classes in TL $(p<0.0001)$, BW $(p<0.0001)$ and liver weight (LW) $(p<0.05)$. No significant differences were found in GSI among three size classes, suggesting same maturation stage in all fishes (Table 1).

Stomach content for each fish was observed for ten randomly chosen samples. However, stomach content for each fish could not identify prey organisms under macro- and micro-observations. Thus, we did not conduct stomach content observations for other 35 fishes.

\section{Fatty acid composition}

Proportions of saturated fatty acids (SAFA) ranged from $55.0 \%$ to $66.5 \%$, with the highest proportions in fatty acids (Table 2). Palmitic acid (16:0) was the most common saturated fatty acid and ranged from 39.9\% to $52.4 \%$ (Table 2) followed by C18:0 and C14:0. Significant differences in SSAFA were found between small fishes (SFs) and medium fishes (MFs) $(p<0.005)$ and between SFs and large fishes (LFs) $(p<0.05)$; however no significant difference was found between MFs and LFs $(p>0.05)$.

Monounsaturated fatty acids (MUFA), which were the second dominant, ranged from $30.7 \%$ to $40.2 \%$ (Table 2).
Of all MUFA, oleic acid $(\mathrm{C} 18: 1 \omega 9 \mathrm{c})$ was the dominant MUFA for all size classes (Table 2). No significant differences were found between all size classes $(p>0.05)$, except for between small fishes and medium and large fishes $(p<0.05)$ in C20:1.

The proportion of polyunsaturated fatty acids (PUFA) was accordingly low; the mean value ranged from $2.8 \%$ to $4.8 \%$ (Table 2). Linolenic acid was highest ranging from $1.1 \%$ to $2.9 \%$, followed by EPA (C20:5n 3 ) and DHA (C22:6n3) (Table 2). No significant differences were found between all size classes $(p>0.05)$.

EPA/DHA ratios in small, medium and large fish were $12.3 \pm 11.7$ (mean $\pm \mathrm{SD}$ ) ranging from 0.7 to $24,2.9 \pm 1.7$ ranging from 0.3 to 5.9 and $1.0 \pm 1.2$ ranging from 0.3 to 3.3 , respectively. No significant differences were found between all size classes $(p>0.05)$.

\section{Fatty acid concentrations}

Fatty acid concentrations increased with fish size (Figures 1, 2 and 3), although correlation coefficients were not "strong" for all relationships. Close positive relationships were found between $\Sigma$ FA, $\Sigma$ SAFA and $\Sigma$ MUFA and TL and BW $(p<0.05-0.0001)$, however no close relationship was found between $\Sigma$ PUFA and TL and BW $(p>0.05)$ (Figure 1).

In SAFA, close positive relationships were found between C14:0, C16:0 and C20:0 and TL and BW $(p<0.05$ 0.0005), however no close relationship was found between $\Sigma$ PUFA and TL and BW ( $p>0.05)$ (Figures 2 and 3). Concentrations of C16:1, C17:1, C18:1 $\omega 9 \mathrm{c}$ and C20:1 in MUFA significantly increased with fish size $(p<0.05-$ $0.0001)$, however no correlations were found between

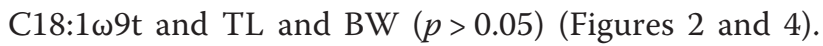
No significant relationships existed between each fatty acid and fish size in PUFA $(p>0.05)$, except for a relation-

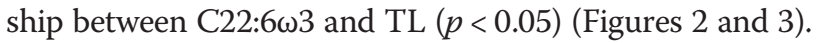

Close negative relationships were found between EPA/ DHA ratios and TL and BW ( $p<0.005$, Figures 2 and 4$)$ suggesting the fish diets are different from their size.

\section{Discussion}

It is noteworthy that fatty acid composition and levels were different depending on the growth stage; both parameters were increased as fish became larger (Figures 1, 2 and 3). Differences in individual fatty acid profiles in relation to development [16,17], food habits [6-11] and

Table 1 Biological information of Lutjanus lutjanus collected in the Bidong Island, Malaysian South China Sea

\begin{tabular}{|c|c|c|c|c|c|c|c|c|c|}
\hline \multirow[b]{2}{*}{ Size class } & \multicolumn{2}{|c|}{ Total length $(\mathrm{cm})$} & \multicolumn{2}{|c|}{ Body weight (g) } & \multicolumn{2}{|c|}{ Liver weight (g) } & \multicolumn{2}{|l|}{ GSI } & \multirow[b]{2}{*}{$\mathbf{N}$} \\
\hline & Mean \pm SD & Range & Mean \pm SD & Range & Mean \pm SD & Range & Mean \pm SD & Range & \\
\hline Small & $14.6 \pm 0.73$ & $13.2-15.6$ & $43.6 \pm 6.99$ & $30.6-54.0$ & $0.244 \pm 0.089$ & $0.110-0.405$ & $0.28 \pm 0.12$ & $0-0.42$ & 12 \\
\hline Medium & $16.3 \pm 0.64$ & $15.2-18.5$ & $60.7 \pm 5.07$ & $48.1-67.9$ & $0.325 \pm 0.090$ & $0.195-0.559$ & $0.24 \pm 0.15$ & $0-0.52$ & 21 \\
\hline Large & $18.1 \pm 0.75$ & $17.0-19.5$ & $79.0 \pm 13.3$ & $62.8-109$ & $0.509 \pm 0.159$ & $0.329-0.868$ & $0.18 \pm 0.18$ & $0-0.46$ & 12 \\
\hline
\end{tabular}

$\mathrm{N}$ : total number of specimens. 
Table 2 Fatty acid composition (mean \pm SD) in livers of Lutjanus lutjanus collected in the Bidong Island, Malaysian South China Sea

\begin{tabular}{|c|c|c|c|}
\hline Fatty acids & Small $(n=3)$ & Medium $(n=7)$ & Large $(n=6$ \\
\hline \multicolumn{4}{|l|}{ SAFA } \\
\hline C14:0 & $7.3 \pm 2.4$ & $4.4 \pm 0.6$ & $4.5 \pm 0.7$ \\
\hline C16:0 & $39.9 \pm 5.9^{a}$ & $52.4 \pm 6.4^{b}$ & $48.6 \pm 8.2^{b}$ \\
\hline C18:0 & $7.6 \pm 2.2$ & $9.4 \pm 5.6$ & $7.4 \pm 4.9$ \\
\hline C20:0 & $0.2 \pm 0.1$ & $0.3 \pm 0.2$ & $0.3 \pm 0.2$ \\
\hline$\Sigma S A F A$ & $55.0 \pm 1.6^{a}$ & $66.5 \pm 7.4^{b}$ & $60.8 \pm 9.2^{b}$ \\
\hline \multicolumn{4}{|l|}{ MUFA } \\
\hline C16:1 & $11.9 \pm 4.9$ & $8.9 \pm 1.4$ & $9.6 \pm 2.6$ \\
\hline C17:1 & $1.2 \pm 0.4$ & $1.1 \pm 0.4$ & $1.4 \pm 0.4$ \\
\hline $\mathrm{C} 18: 1 \omega 9 c$ & $13.2 \pm 1.3$ & $12.0 \pm 3.0$ & $15.1 \pm 6.4$ \\
\hline 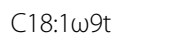 & $13.7 \pm 3.5$ & $7.6 \pm 5.8$ & $9.5 \pm 6.0$ \\
\hline C20:1 & $0.1 \pm 0.1^{a}$ & $1.1 \pm 1.2^{b}$ & $0.8 \pm 0.4^{b}$ \\
\hline$\Sigma$ MUFA & $40.2 \pm 2.2$ & $30.7 \pm 8.0$ & $36.4 \pm 9.3$ \\
\hline \multicolumn{4}{|l|}{ PUFA } \\
\hline C18:3n6 & $0.04 \pm 0.1$ & $0.1 \pm 0.1$ & $0.1 \pm 0.1$ \\
\hline$C 18: 3 n 3$ & $2.9 \pm 1.6$ & $1.5 \pm 0.6$ & $1.1 \pm 0.3$ \\
\hline$C 20: 3 n 3$ & $0.03 \pm 0.05$ & $0.02 \pm 0.04$ & $0.01 \pm 0.03$ \\
\hline C20:5n3 (EPA) & $1.4 \pm 0.4$ & $0.6 \pm 0.2$ & $0.6 \pm 0.3$ \\
\hline $\mathrm{C} 22: 6 \mathrm{n} 3(\mathrm{DHA})$ & $0.5 \pm 0.7$ & $0.5 \pm 0.8$ & $1.1 \pm 0.8$ \\
\hline EPA/DHA & $12.3 \pm 11.7$ & $2.9 \pm 1.7$ & $1.0 \pm 1.2$ \\
\hline$\Sigma$ PUFA & $4.8 \pm 1.4$ & $2.8 \pm 1.1$ & $2.8 \pm 1.1$ \\
\hline
\end{tabular}

${ }_{\mathrm{a}, \mathrm{b}}$ Means in the same row with different superscript differ significantly $(p<0.05)$.

habitat use [18-20], temperature [18] and salinity [20,21] have been reported in different fish species. However, differences in fatty acid composition and levels in relation to body size in wild fish species have not been well established. Although the mechanism of lipid deposition in the liver of fish fed diets was still uncertain, fatty acid synthesis was regulated by liver $\mathrm{X}$ receptor suggesting the profiles of the liver reflected diets of fish [22]. It is likely that such differences are caused by differences in the diet, behavior and migration of L. lutjanus accompanying the growth. The role of seagrass beds and mangroves as nursery habitats for some fish species has received considerable attention as a link with adjacent coral reef or offshore habitats [23-25]. The spatial size distribution of snappers (Lutjanidae) has previously indicated the separation of juveniles in nursery habitats from the adults on the coral reef [26]. In the ontogeny of Lutjanidae, a major change in diet occurred at a sizeclass that corresponded to the size at which these individuals were first observed on the coral reef [26]. The diet shifts of snapper (Lutjanidae) species that inhabit seagrass beds and mangroves have been reported during their juvenile and sub-adult stages [26-28]. In the case of

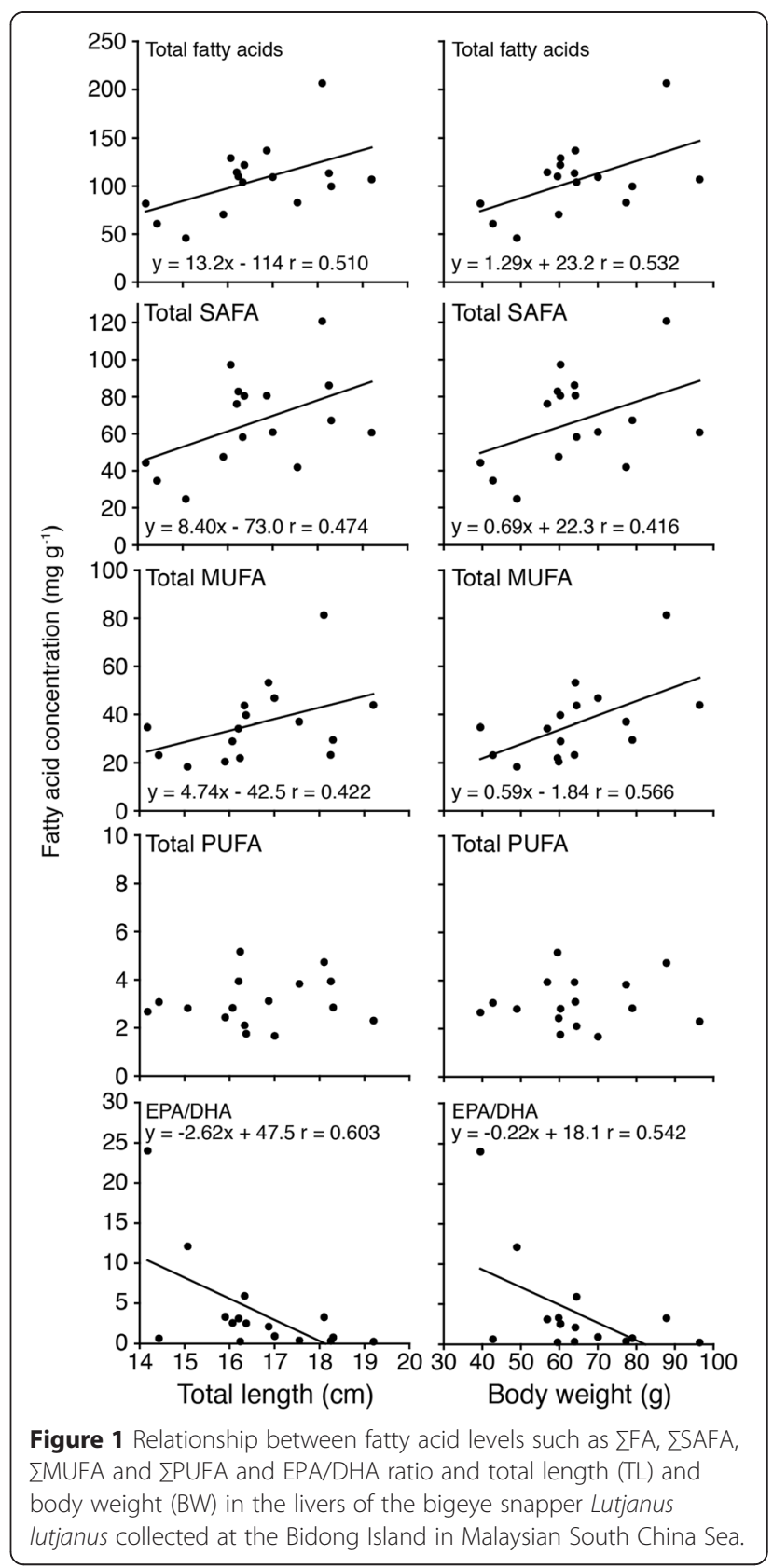

Lutjanidae, the size at the critical diet shift corresponded to the smallest size at which these species were observed on the adjacent reef [26]. The major diet shift and diet change are suggested to play an important role in determining their migration patterns [26]. These findings suggest that differences in fatty acid profile during growth found in the present study might correspond to the diet and habitat shifts in L. lutjanus.

SAFA was the most abundant fatty acids and the palmitic SAFA showed highest values among all fatty acids (Table 2). The second most abundant SAFA was stearic acid. These two SAFAs have been reported to have the highest concentrations in other fish species [29,30], Acetes 


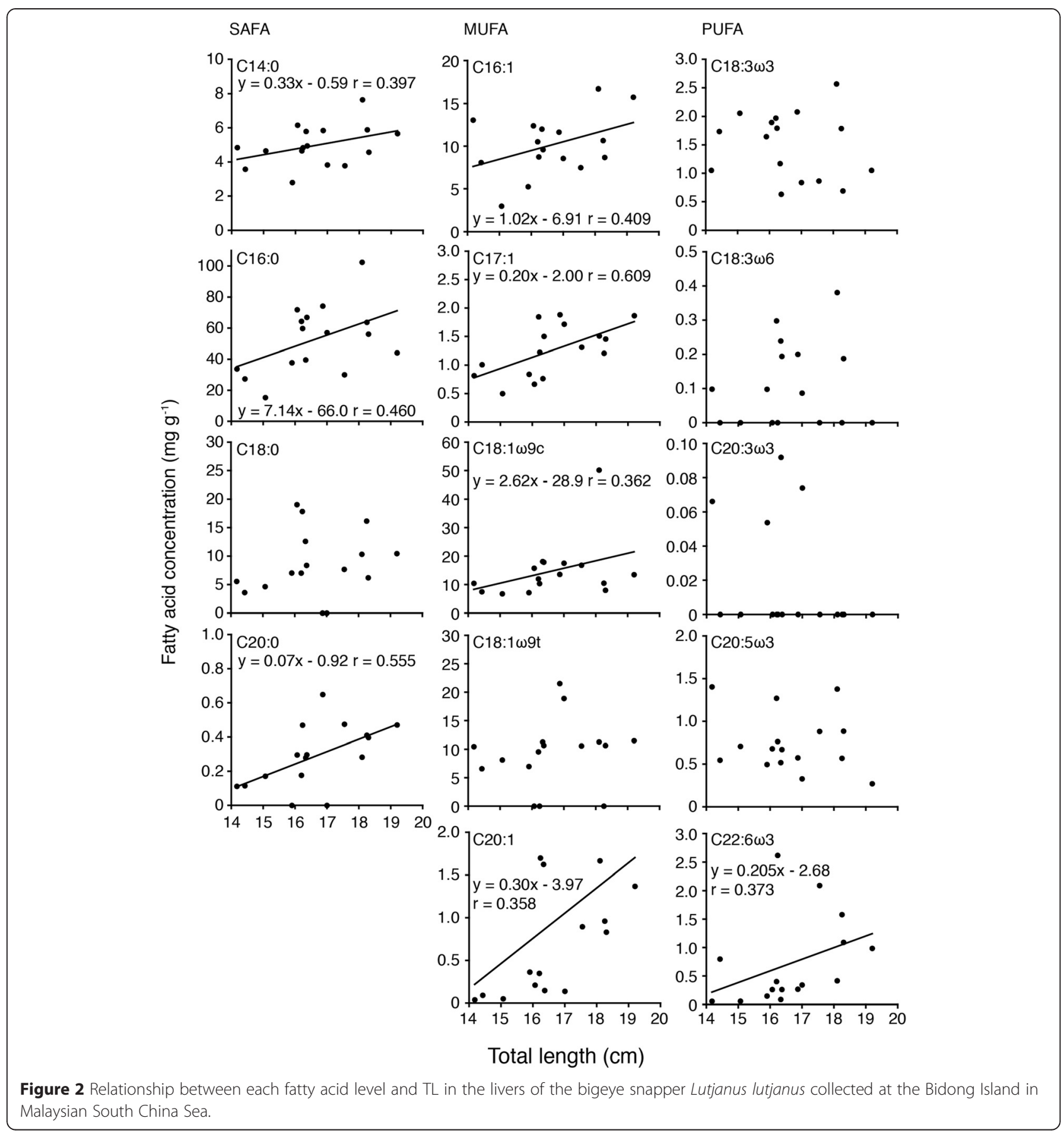

[31] and copepods [32]. The predominance of both fatty acids has been attributed to their use as a major source of energy for metabolism and growth [33]. Fishes from warm waters tend to show high levels of palmitic and stearic acids compared to those from cold waters [34]. This difference is due to metabolic differences between cold and warm water species, because these fatty acids are not usually subject to differences in diet [34]. The bigeye snapper Lutjanus lutjanus was collected in the South China Sea in tropical waters in the present study, and thus the fish might have higher palmitic and stearic acid levels.

MUFA was the second most abundant fatty acid, with highest values for oleic acid (Table 2). This is in agreement with findings in copepods [35], Acetes [31] and fish fatty acid profiles $[29,30,34]$. Oleic MUFA is naturally occurring in large concentrations in many marine organisms, which can also synthesise this MUFA de novo [33]. High proportions of MUFAs of marine predators are generally derived from marine zooplankton in particular 


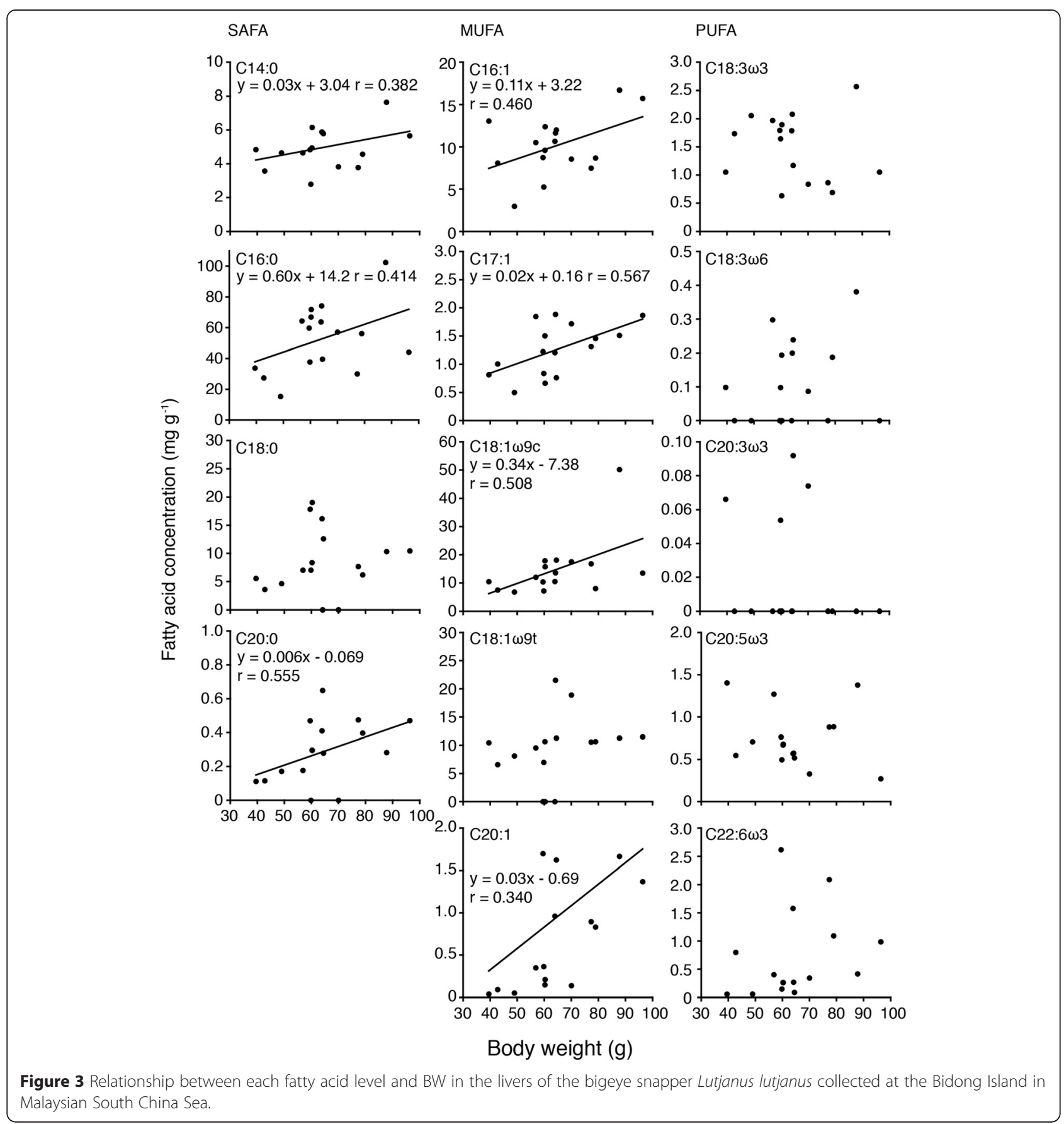

calanoid copepods such as Calanoides acutus and Calanus propinquus in Antarctic waters [36,37]. Recently, damselfish species Abudefduf bengalensis and A. sexfasciatus collected in coral reef are of the South China Sea, showed the high proportion of MUFAs [10,11,38]. These fishes have been suggested to consume marine zooplankton $[10,11,38]$. In the present study, we did not conduct fatty acid analyses for potential prey organisms. Nevertheless, the higher level of MUFAs found in Lutjanus lutjanus suggest that the fish might feed copepod as one of potential prey organism during the life history.

EPA and DHA showed the highest levels among PUFA (Table 2). These two PUFAs are also known as highly unsaturated fatty acids. EPA:DHA ratios ranged from 1.0 to 12.3 in Lutjanus lutjanus (Table 2). EPA:DHA ratios of copepods Acartia erythraea, shrimps Lucifer penicillifer and Acetes intermedius and A. erythraeus and pelagic fishes such as anchovy, sardine and scad ranged from 0.1 to 1.2 collected in the Mindanao Sea, Philippines [39] 


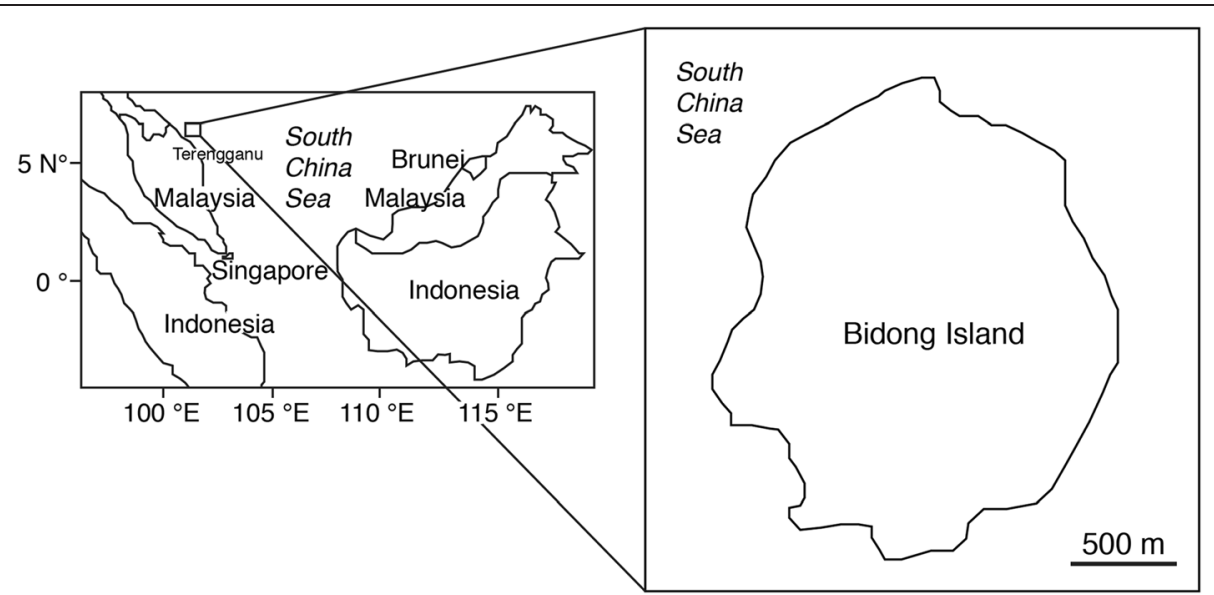

Figure 4 Map showing the location of the study site at the Bidong Island in Malaysian South China Sea, off the Terengganu State in the east coast of Peninsula Malaysia.

where is geographically close to the South China Sea. The ratios suggest that Lutjanus lutjanus might feed copepods, shrimps and small pelagic fishes in coral ecosystem.

\section{Conclusions}

Fatty acid signature has been increasingly used to study the diet of a number of marine species. The present study suggests that diets of the coral fish species Lutjanus lutjanus changed in accordance with growth. Furthermore, differences in fatty acid profiles might not just be considered with respect to the diets, but might be based on the habitat and migration. Further studies are needed to study for various organisms in coral ecosystem using fatty acid signature for understanding life history and ecology details in the coral fish species.

\section{Methods}

\section{Fish}

All specimens of the bigeye snapper Lutjanus lutjanus were collected at the Bidong Island in the South China Sea, Malaysia $\left(05^{\circ} 37^{\prime} 12^{\prime \prime} \mathrm{N}, 103^{\circ} 04^{\prime} 12^{\prime \prime}\right.$ E) between 27 and 28 October 2013 (Figure 4). Bidong Island is located off Terengganu State on the east coast of Peninsular Malaysia, known for its well-developed coral reef ecosystems that support a variety of coral and rocky reef associated fishes [40]. All fishes were collected by means of fish traps and hook and line. After collecting, all fishes were immediately stored in ice chest, brought back to laboratory, were kept in $-20^{\circ} \mathrm{C}$ freezer. Fatty acid analyses were conducted within one month after sampling. A total of 45 fish samples were measured in total length (TL), body weight (BW), and each fish was dissected in order to determine liver and gonad weights (Table 1). In the present study, fishes were categorised as either small, medium or large according to their sizes (Table 1). Stomach for each fish was dissected for the content analyses.
Gonadosomatic index (GSI) for each fish was calculated with the formula

$$
G S I=G W B W^{-1} \times 100
$$

\section{Fatty acid analysis}

Liver samples of Lutjanus lutjanus were analysed for fatty acid composition following the one step method [9-11]. Liver samples were combined to form pooled tissue samples for each size group. The sample sizes of small, medium and large groups were three, seven and six, respectively (Table 2). Each liver sample was mixed with $4 \mathrm{ml}$ of hexane (Merck, Germany) and $1 \mathrm{ml}$ of internal standard solution in a $50 \mathrm{ml}$ centrifuge tube. After adding $2 \mathrm{ml}$ of $14 \% \mathrm{BF} 3$ in methanol, the tube was flushed with nitrogen gas. The capped tube was heated on a hot plate at $100^{\circ} \mathrm{C}$ for $120 \mathrm{~min}$. One $\mathrm{ml}$ of hexane was added followed by $2 \mathrm{ml}$ of distilled water. The tube was then shaken vigorously for $1 \mathrm{~min}$ and centrifuged (MSE Harrier 15/80, MSE Ltd., United Kingdom) for $3 \mathrm{~min}$ at $2500 \mathrm{rpm}$.

Samples were then analysed using a GC-FID (GC 14-B, Shimadzu, Japan). Separation was performed with an FFAP-polar capillary column $(30 \mathrm{~m} \times 0.32 \mathrm{~mm}$ internal diameter, $0.25 \mu \mathrm{m}$ film thickness). Hydrogen was used as a carrier gas. After injection at $60^{\circ} \mathrm{C}$, the oven temperature was raised to $150^{\circ} \mathrm{C}$ at a rate $40^{\circ} \mathrm{C} \mathrm{min}{ }^{-1}$, then to $230^{\circ} \mathrm{C}$ at

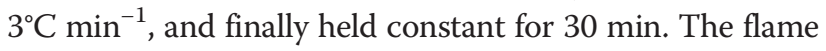
ionization was held at $240^{\circ} \mathrm{C}$. Peaks were identified by comparing their retention times with those of authentic standards (Supelco Inc., Sigma-Aldrich, USA). Fatty acids were designated as an $n: p \omega x$, where $n$ is the number of carbon atoms in the aliphatic chain, $p$ is the number of double bonds and $\mathrm{x}$ is the position of the first double bond 
from the terminal methyl group. The analytical precision for samples was generally $<5 \%$ for each sample replication.

\section{Data analyses}

Fatty acid concentrations ( $\mathrm{mg} \mathrm{g}^{-1}$ dry weight) were calculated by comparing the peak area of fatty acid in the sample with the peak area of internal standard. The percentage for each fatty acid was converted from the area of chromatogram peaks. The composition is expressed as percentage of total fatty acids (Table 2).

Differences between data were analysed using the Mann-Whitney $U$-test. Differences among data were also examined using the Kruskal-Wallis test while using the Mann-Whitney $U$-test for post hoc two-group comparisons. The significance of the correlation coefficient and the regression slope were determined using a $t$-test [41].

\section{Competing interests}

The authors declare that they have no competing interests.

\section{Authors' contributions}

RA performed the field survey and experiments described in this study. ZB supervised the experiments described in this study. TA performed the field survey, supervised the experiments, analyzed the data and wrote the manuscript. All the authors read and approved the final manuscript.

\section{Acknowledgements}

The authors are grateful to staffs in Universiti Malaysia Terengganu for their kind assistance with the field survey. This work was supported by the Higher Institution Centre of Excellence (HICoE) Research Grant (Vot No. 66928), under the Institute of Oceanography and Environment (INOS).

\section{Author details}

${ }^{1}$ Institute of Oceanography and Environment, Universiti Malaysia Terengganu, 21030, Kuala Terengganu, Terengganu, Malaysia. ${ }^{2}$ School of Marine Science and Environment, Universiti Malaysia Terengganu, 21030, Kuala Terengganu, Terengganu, Malaysia.

Received: 18 January 2015 Accepted: 19 March 2015 Published online: 18 April 2015

\section{References}

1. Burke L, Selig E, Spalding M. Reefs at risk in Southeast Asia. World Resources Institute: Washington, DC; 2002.

2. Mohsin AKM, Ambak MA. Marine fishes and fisheries of Malaysia and neighbouring countries. Serdang: Agriculture University of Malaysia Press; 1996.

3. Ambak MA, Isa MM, Zakaria MZ, Ghaffar MA. Fishes of Malaysia. Kuala Terengganu: Universiti Malaysia Terengganu; 1991.

4. Chong VC, Lee PKY, Lau CM. Diversity, extinction risk and conservation of Malaysian fishes. J Fish Biol. 2010;76:2009-66.

5. Arai T. Diversity and conservation of coral reef fishes in the Malaysian South China Sea. Rev Fish Biol Fisheries. 2015;25:85-101.

6. Daly EA, Benkwitt CE, Brodeur RD, Litz MNC, Copeman LA. Fatty acid profiles of juvenile salmon indicate prey selection strategies in coastal marine waters. Mar Biol. 2010;157:1975-87.

7. Stowasser G, Pond DW, Collins MA. Fatty acid trophic markers elucidate resource partitioning within the demersal fish community of South Georgia and Shag Rocks (Southern Ocean). Mar Biol. 2012;159:2299-310.

8. Couturier LIE, Rohner CA, Richardson AJ, Marshall AD, Fabrice RA, Jaine FRA, et al. Stable isotope and signature fatty acid analyses suggest reef manta rays feed on demersal zooplankton. PLoS One. 2013:8(10):e77152.

9. Arai T, Amalina R, Bachok Z. Similarity in the feeding ecology of parrotfish (Scaridae) in coral reef habitats of the Malaysian South China Sea, as revealed by fatty acid signatures. Biochem Sys Ecol. 2015;59:85-90.
10. Arai T, Amalina R, Bachok Z. Growth effect on liver fatty acid composition of damselfishes genus Abudefduf collected in coral reef habitats of the Malaysian South China Sea. SpringerPlus. 2015;4:71

11. Arai T, Amalina R, Bachok Z. Fatty acid composition indicating diverse habitat use in coral reef fishes in the Malaysian South China Sea. Biol Res. 2015;48:13.

12. Sargent JR, Parkes JR, Mueller-Harvey I, Henderson RJ. Lipid biomarkers in marine ecology. In: Sleigh MA, editor. Microbes in the sea. Chichester: Ellis Horwood Ltd.; 1987. p. 119-38.

13. Allen GR. FAO species catalogue. Snappers of the world. An annotated and illustrated catalogue of lutjanid species known to date. FAO Fisheries Synopsis no. 125, volume 6. Food and Agricultural Organization of the United Nations: Rome; 1985.

14. Allen GR. Genus Lutjanus. In: Smith MM, Heemstra PC, editors. Smiths' sea fishes. Berlin, Heidelberg, New York: Spriger-Verlag; 1986. p. 572-9.

15. Froese R, Pauly D. FishBase 2000: concepts, design and data sources. Los Baños, Laguna, Philippines: ICLARM; 2000.

16. Legendre $M$, Kerdchuen N, Corraze G, Bergot P. Larval rearing of an African catfish Heterobranchus longifilis (Teleostei, Claridae): effect of dietary lipids on growth, survival and fatty acid composition of fry. Aquat Living Resour. 1995;8:355-63.

17. Soivio A, Niemistö M, Bäckström M. Fatty acid composition of Coregonus muksun Pallas: changes during incubation, hatching, feeding and starvation. Aquaculture. 1989;79:163-8.

18. Takeuchi T, Watanabe T. The effects of starvation and environmental temperature on proximate and fatty acid composition of carp and rainbow trout. Bull Jpn Soc Sci Fish. 1982;48:1307-16.

19. Tidwell JH, Webster CD, Clark JA. Effects of feeding, starvation, and refeeding on the fatty acid composition of channel catfish, Ictalurus punctatus, tissues. Comp Biochem Physiol. 1992;103A:365-8.

20. De Silva SS, Gunasekera RM, Austin CM. Changes in the fatty acid profiles of hybrid red tilapia, Oreochromis mossambicus $\times 0$. niloticus, subjected to short-term starvation, and a comparison with changes in seawater raised fish. Aquaculture. 1997;153:273-90.

21. Borlongan IG, Benitez LV. Lipid and fatty acid composition of milkfish (Chanos chanos Forsskal) grown in freshwater and seawater. Aquaculture. 1992;104:79-89.

22. Peng M, Xu W, Mai K, Zhou H, Zhang Y, Liufu Z, et al. Growth performance, lipid deposition and hepatic lipid metabolism related gene expression in juvenile turbot (Scophthalmus maximus L.) fed diets with various fish oil substitution levels by soybean oil. Aquaculture. 2014;433:442-9.

23. Pollard DA. A review of ecological studies on seagrass-fish communities, with particular reference to recent studies in Australia. Aquat Bot. 1984;18:3-42.

24. Parrish JD. Fish communities of interacting shallow-water habitats in tropical oceanic regions. Mar Ecol Prog Ser. 1989;58:143-60.

25. Beck MW, Heck KL, Able KW, Childers DL, Eggleston DB, Gillanders BM, et al. The identification, conservation, and management of estuarine and marine nurseries for fish and invertebrates. Bioscience. 2001;51:633-42.

26. Cocheret de la Morinière E, Pollux BJA, Nagelkerken I, van der Velde G. Diet shifts of Caribbean grunts (Haemulidae) and snappers (Lutjanidae) and the relation with nursery-to-coral reef migrations. Estuar Coast Shelf Sci. 2003;57:1079-89.

27. Nagelkerken I, Dorenbosch M, Verberk WCEP, Cocheret de la Morinière $E$ van der Velde G. Importance of shallow-water biotopes of a Caribbean bay for juvenile coral reef fishes: patterns in biotope association, community structure and spatial distribution. Mar Ecol Prog Ser. 2000;202:175-92.

28. Cocheret de la Morinière E, Pollux BJA, Nagelkerken I, van der Velde G. Post-settlement life cycle migration patterns and habitat preference of coral reef fish that use seagrass and mangrove habitats as nurseries. Estuar Coast Shelf Sci. 2002:55:309-21.

29. Sahena F, Zaidul ISM, Jinap S, Saari N, Jahurul HA, Abbas KA, et al. PUFAs in fish: extraction, fractionation and importance in health. Compr Rev Food Sci F. 2009:8:59-74.

30. Elsdon TS. Unraveling diet and feeding histories of fish using fatty acids as natural tracers. J Exp Mar Biol Ecol. 2010;386:61-8.

31. Montaño N, Gavino G, Gavino VC. Polyunsaturated fatty acids of some traditional fish and shrimp paste condiments of the Philippines. Food Chem. 2001;75:155-8.

32. van der Meeren T, Olsen RE, Hamre K, Fyhn HJ. Biochemical composition of copepods for evaluation of feed quality in production of juvenile marine fish. Aquaculture. 2008;274:375-97. 
33. Sargent JR, Tocher DR, Bell JG. The lipids. In: Halver JE, Hardy RW, editors. Fish nutrition. 3rd ed. San Diego: Academic; 2002. p. 181-257.

34. Huynh MD, Kitts DD. Evaluating nutritional quality of pacific fish species from fatty acid signatures. Food Chem. 2009;114:912-8.

35. Olivotto I, Tokle NE, Nozzi V, Cossignani L, Carnevali O. Preserved copepods as a new technology for the marine ornamental fish aquaculture: A feeding study. Aquaculture. 2010;308:124-31.

36. Pond DW, Tarling GA. Phase transitions of wax esters adjust buoyancy in diapausing Calanoides acutus. Limnol Oceanogr. 2011;56:1310-8.

37. Pond DW, Tarling GA, Ward P, Mayor D. Wax ester composition influences the diapause patterns in the copepod Calanoides acutus. Deep-Sea Res II. 2012;59-60:93-104.

38. Arai T, Amalina R, Bachok Z. Diverse feeding ecology and habitat use in coral reef fishes in the Malaysian South China Sea, as revealed by liver fatty acid composition. Oceanol Hydrobiol Stud. 2015:44:120-26.

39. Metillo EB, Aspiras-Eya AA. Fatty acids in six small pelagic fish species and their crustacean prey from the Mindanao Sea Southern Philippines. Trop Life Sci Res. 2014;25:105-15.

40. Matsunuma M, Motomura $H$, Matsuura K, Shazili NAM, Ambak MA. Fishes of Terengganu East coast of Malay Peninsula, Malaysia. National Museum of Nature and Science, Tokyo, Universiti Malaysia Terengganu. Kagoshima: Terengganu, and Kagoshima University Museum; 2011.

41. Sokal RR, Rohlf FJ. Biometry. 3rd ed. New York: Freeman and Company; 1995

\section{Submit your next manuscript to BioMed Central and take full advantage of:}

- Convenient online submission

- Thorough peer review

- No space constraints or color figure charges

- Immediate publication on acceptance

- Inclusion in PubMed, CAS, Scopus and Google Scholar

- Research which is freely available for redistribution 